China and its problems, as well as a rapid increase of business contacts with China.

We hope that the Polish-Chinese Friendship Association will gradually develop as we believe that its goals are noble and the social support for its activity is steadily increasing. China will continue to grow and its contribution to the progress of whole world will be more and more significant.

\title{
Problems connected with professional and academic careers in the so-called post-doctoral phase: Polish and French experiences
}

\author{
by Stanisław Roszak
}

First of all, I would like to highlight the fact that discussion about the system and mechanisms of self-development of young researchers in the post-doctoral phase in Poland has only just begun. The problem became very serious when we started to implement the guidelines of the Strategy of Bologna, which means introducing three educational stages: Bachelor's degree (after 3 years spent at the university), Master's degree (after next two years), and Doctorate degree (four years). My paper will concentrate on three main issues:

- changes in the Polish educational system and their influence on people's careers;

- the present situation in doctoral and post-doctoral studies;

- perspectives and suggestions for future solutions, based on Polish and French examples.
The traditional model for the academic career in Poland used to function mainly thanks to a direct relation between a master and his student-follower. The professor, who was the master, was simply employing the student as his assistant. Such an assistant was supposed to prepare a dissertation during eight years. After its acceptance by a proper Department Board he was employed as a senior lecturer. Then he had nine years in order to write a habilitation thesis and thanks to it he acquired the status of an independent worker, capable of teaching the next generations, including his own assistants.

Today we need to ask if this old relation between master and student can be kept. On the one hand doctoral studies are getting more and more popular, while on the other students are obliged to take part in various lectures and seminars which 
are given by different researchers, not only by the master. Such a process can be observed while analyzing the development of doctoral studies at the Department of History at the Nicolaus Copernicus University. ${ }^{1}$ In 1993, when the recruitment for doctoral studies began, five people were accepted, all of whom, after four years of studies, achieved the doctorate degree. Four of them were employed in the Institute of History and Archival Sciences, one by another university. As they found jobs in the departments of their masters, we can say that an initial phase of doctoral studies' system used to consolidate this old relationship between the master and his student.

At present, one hundred and seventeen students participate in doctoral studies in the Faculty of Historic Arts. Last year nobody from that group found employment at the Nicolaus Copernicus University and only few managed to find a job somewhere else. Therefore, the doctoral studies became just the third phase of higher education, no longer enabling them to acquire experience and abilities thanks to cooperation with the master.

1 More about development of the doctoral studies in history at the Nicolaus Copernicus University in: W. Chorążyczewski, S. Roszak, System kształcenia historyków na UMK w Toruniu w latach 1945-2005, [in:] Homines et Historia VI. Instytut Historii i Archiwistyki Uniwersytetu Mikołaja Kopernika (1945-2005). Wybrane problemy, ed. J. Sziling, Toruń 2006, pp. 224-228.
Introducing the so-called Lisbon Strategy brings about serious consequences for the future. Answers to two key questions must be found:

- who do we teach in doctoral studies? who should we teach?

- what happens after the doctoral studies? what should the model of an academic and professional career look like?

During the seminar "The model of doctoral education," organized in 2007, it was pointed out that the Lisbon Strategy means increasing expenses on research. Until 2010 in the European Union three per cent of income should be allocated for professional research. In such a way, about seven hundred thousand places of work would be created. Minority (ten per cent only) would be connected with the universities, while the rest with the economy. Nowadays in Poland there are six thousand PhDs every year and only a tiny part of them finds employment at the universities.

That is why careful consideration of the educational model is needed, as well as a new answer on the question of exactly what the doctorate degree means in these times.

When we accept the professional point of view, we perceive the doctorate as the beginning of a career, but from the perspective of the national economy it is usually the end of an academic career and at the same time a start of implementation 
of particular projects useful for the purposes of industry.

In practice there is a division between research $(\mathrm{PhD})$ and professional doctorates (of Law, Education or Medicine), but this functions well in the American system. In the Polish educational system doctoral studies are supposed to prepare for independent academic work. They do not prepare for work anywhere else but the academic sector. So the student after the doctoral studies, when there is no traditional bond between a student and his master, seems to be totally helpless. There is no possibility to stay at the university and continue the master's work, and no chance to compete with other people while looking for a job because of lack of qualifications, which are desired by employers. ${ }^{2}$

The situation of graduates has been discussed for a few years. I would like to present the ideas and some solutions, based on Polish and French experience.

Last year in France a book prepared by Conseil Superieur de la recherche et de la technologie came out. It was entitled Jeunes chercheurs et jeunes enseignantschercheurs. Statut et condition de travail. ${ }^{3}$

\footnotetext{
2 Naturally, it is not only a Polish problem. Recently, the problem of rising unemployment of the young PhDs in Germany and the question of an adaptation of the educational system to the market have been presented in a special magazine issue "Uni - Spiegel" 2010, No. 4 , Ausgebeutet. Vielen Doktoranden geht es schlecht, pp. 8-14.

3 Jeunes chercheurs et jeunes enseignants-cher-
}

In fact, it is a report which includes solutions connected with the status of a young researcher in France. Its aim is to present a situation of so-called "young researchers," that is, in the six-year period after finishing doctoral studies.

The report touches on certain essential issues:

1) first of all, the age of employment in different sectors of the economy and administration and at the universities. Above all, it is necessary to say that age limits for graduating from doctoral studies, at least in national administration, should be abolished. People with the Doctorate's degree in their thirties become permanently employed by the universities, and in case of the humanities the average age is bound to be a bit higher. ${ }^{4}$

2) secondly, a problem of equal chances for women after the doctoral studies. Nowadays, there is an occurrence called the leaky pipeline which means that a number of women on further stages of an academic career is decreasing. Women constitute fifty seven per cent of students who finish the first phase of university education, and only ten per cent of them become professors. ${ }^{5}$

\footnotetext{
cheurs. Statut et condition de travail, La documentation française, Paris 2007.

4 The problem has been discussed in chapter 11: Les offres de carrières de recherche dans les EPST, les EPIC et les EPCSCP - statut, modalité de recrutement, perspectives de carrière, pp. 107-124.

5 See chapter 10: Âge et parité, pp. 99-106.
} 
The report suggests following solutions:

- employing post-PhD students within a framework of a scientific contract for three or five years. (I must highlight the fact that contracts concluded by the Institut National de la santé et de la recherche medicale brought very good results. Thirty six researchers from the whole number of thirty nine taking part in a programme "Avenir," found permanent employment. These contracts are concluded with hospitals, universities, local administration and factories);

- employing post-PhDs for three or five years at the universities, enabling the completion of particular academic projects (without the necessity of lecturing);

- creating a two-year contracts for post-PhD students, preparing them to work in the public and the private sector; such contracts would be financed by the government;

- organizing experience for post$\mathrm{PhDs}$, in their own country and abroad. It is important to increase the mobility of young researchers in three aspects: they should spend some time abroad, they ought to be ready to change the university after achieving the Doctorate degree, and finally, they must be open-minded enough to engage in other problems in their field of interest;

- creating a school for post-PhDs, which would be supervised by the biggest universities;
- creating "La Mission nationale des carrieres scientifiques et techniques." Its main task is to work out the legal status of a young researcher in order to encourage people to take up academic research. It is extremely important to secure his future after the doctoral studies. Such an attitude results from a position taken up by the European Commission, which in March 2005 pointed out the necessity to be precise about the status of a young researcher. "Le statut postdoctoral devrait être transitoire," which means that a post-PhD after completing a particular scientific project should be employed. All these activities are supposed to make the career of a young post- $\mathrm{PhD}$ more attractive. The Conseil Superieure as an example mentions solutions developed in Finland but it doesn't give any details.

Polish examples: In Poland, the problem of the future of post-PhDs is being discussed. Amongst the postulates there are some dominating ideas, ${ }^{6}$ that is:

- financial support from the Foundation for Polish Science and Ministry of Science and Higher Education (and other foundations) for research projects com-

\footnotetext{
6 Discussion on the professional status of a young $\mathrm{PhD}$, who has finished the doctoral studies, has taken place for a few years. The recording of this discussion can be found in the following magazines: "Nauka" 2000, No. 4 and "Forum Akademickie" 2006, No. 5.
} 
pleted in two or three years' time (research grant);

- organization of periods of practice in different scientific institutions and at the universities, lasting one or two years, in Poland or abroad; nowadays such practices are organized in cooperation with Foundation for Polish Science and National Institute of Health-Research Career Transition Award Program. What is more important is the fact that young researchers, after returning to Poland, can obtain additional support within a framework of the programme "Columbus," just as in France. It is believed it stops the young researchers leaving the country;

- preparations for work beyond the university.

At the Nicolaus Copernicus University two interesting initiatives have recently appeared. They concern the future of postPhDs.

The first one is strictly connected with academic self-development. The Institute of Philosophy organizes postdoctoral seminars which touch problems of values and ethics. They also enable the integration of young researchers, as they can meet once a month to discuss and present the results of their researches. ${ }^{7}$

\footnotetext{
7 At the Nicolaus Copernicus University there are post-doctoral seminars in practical philosophy organized by professors Włodzimierz Tyburski and Ryszard Wiśniewski.
}

The second example I would like to mention is "Internationales Thorner Doktorandenkolleg." It is a project bringing together students and $\mathrm{PhDs}$ from Poland and Germany. Under the direction of the experienced academics, further research will be undertaken and various projects will be carried out. It is a PolishGerman initiative, which has financial support from the European Union, the Ministry of Science and Higher Education and Nicolaus Copernicus University. It is worth mentioning that the idea of such common projects is popular in the European Union. So exchanges of young academics, practice at the universities abroad, finding special funds for joint research programmes is not something new. Within the framework of a programme "People," the seventh programme of the European Community will be achieved. It is prepared for the period of 2007-2013. It popularizes activities connected with the education of researchers; it is responsible for finding funds necessary to enable the development of their professional careers (so called Marie Curie grants); it supports the mobility of young researchers. Amendment number 49 states: it is possible to support postdoctoral posts for researchers coming from new members of the European Union, in order to enable them to participate in existing research groups in other countries belonging to the $\mathrm{EU}$. 